\title{
Utilization of Volcanic Tuffs as Construction Materials
}

\author{
Kamel Al-Zboon' ${ }^{1}$, Jehad Al-Zou'by ${ }^{1}$, Ziad Abu-Hamatteh ${ }^{2}$ \\ 1) Environmental Engineering Department, Al-Huson University College, Al-Balqa Applied University, Irbid, Jordan. \\ ${ }^{2)}$ Civil Engineering Departments, Faculty of Engineering Technology, Al-Balqa Applied University, Amman, 11134 Jordan
}

The current study examines the possibility of utilizing the Jordanian volcanic tuff aggregates as a source of many construction materials. Different mixtures were prepared by replacing the commonly used normal aggregate with volcanic tuffs aggregate to determine the best mixing proportion with similar size in different ratios as $0,25,50,75$ and $100 \%$. The impacts of this replacement on brick's compression strength, dry weight and water absorption, transverse strength, absorption and weight of terrazzo tiles, loss Anglos and CBR values have been examined and evaluated. The results revealed an improvement in compressive strength of bricks at a replacement ratio of $25 \%$, with concomitant reduction at higher replacement ratios, while water absorption increased as the ratio of tuff increases. Transverse strength of terrazzo tiles was recorded as 6.08, 5.78, 5.78, 5.21 and $5.19 \mathrm{MPa}$ at substitution ratios of $0,25,50,75$ and $100 \%$, respectively. Utilization of volcanic tuffs resulted in a significant reduction in the dry weight of bricks and terrazzo provided lightweight material. CBR test indicated that this material can be used successfully in foundations and as a sub-base material. The obtained results buttressed the benefit of utilization of natural volcanic tuffs as construction materials.

Keywords: Volcanic Tuffs, Construction Materials, Terrazzo Tiles, Bricks, Pavement Materials, Jordan.

\section{Introduction}

Selection and preparation of construction materials are of prime importance in all major engineering projects, including road pavements, concrete mixes and other construction materials such as tiles and bricks. The engineering properties of the construction materials are supposed to meet the standards in order to achieve the minimum requirements in terms of strength and durability. (Bell, 2007). The selection of construction materials basically depends on the common index properties of rocks, such as durability, strength, density permeability, and porosity. Other interference conditions such as climate conditions, project purposes and cost-effectiveness should be considered during the selection and preparation process of the construction materials. The utilization of the local construction materials while maintaining the required properties and specifications represent a challenge for civil engineering all over the world (McLean and Gribble, 2005; Rahn, 1996; Johnson and DeGraff 1988). In light of the overpoweringly increasing demand for raw materials by various construction, sectors created a serious shortage in some building materials. Therefore, in order to meet the dramatically increasing demand, uncommon sources of such materials with acceptable engineering properties becomes precedence. Volcanic tuff (VT) is considered as a promising source of natural construction materials. Volcanic tuff, one of the most important natural pozzolan materials, has been used since ancient times in buildings, bridges, walls, and masonry works. Currently, it is used in many countries in the world for masonry mortars, lightweight concretes and thermal for acoustic insulation materials (Balog et al., 2014). Volcanic tuff with its unique structure and unique properties could serve as a construction material in many engineering projects. Tuff is a relatively soft, high porous with high surface area and low-density igneous rock formed from volcanic ash or dust (Al-Zboon and Al-Zou'by, 2017). It is considered as a good inexpensive source for lightweight aggregate concrete leading to a considerable cost saving in various construction materials (Turkmenoglu and Tankut 2002; Negis, 1999; K1lıçarslan, 2011). The feasibility of using volcanic tuff as a light-weight aggregate in cement and concrete industry has been reported by many researchers (Turkmenoglu and Tankut 2002; Al-Zboon and Al-Zou'by, 2017; USBR, 1992; Kan and Gul, 1996; Kilic et al., 2009; Augenti and Parisi, 2010; Faella et al., 1992; Smadi and Migdady, 1991; Kavasa and Evcin, 2005; Abali et al., 2006). The specific gravity of VT is about 1.84, while it is about 2.52 for ordinary sand. For this reason, VT can provide lightweight concrete with a density of $1440-1840 \mathrm{~kg} / \mathrm{m}^{3}$ in comparison with $2400 \mathrm{~kg} / \mathrm{m}^{3}$ for normal aggregate concrete (Fredrick, 2014). Al-Zboon and Al-Zou'by (2017) used VT for concrete production and the results showed significant improvement in compressive and flexural strength at a replacement ratio of $25 \%$, with reductions at higher ratios. Al-Zou'by and Al-Zboon (2014) utilized VT in cement mortar and found that a replacement ratio of 50\% enhanced compressive strength and flexural strength. Yasin et al., (2012) studied the Jordanian tuffs for use in concrete production and they replaced $20 \%$ of the fine aggregates by volcanic tuff and thereby the concrete compressive strength improved significantly. Moreover, Fredrick (2014) replaced normal sand with VT in concrete mixes and reported an increase in the compressive strength of concrete cubes with $2.8 \%, 7.4 \%, 11.1 \%$ and $14.0 \%$ and $5.0 \%$ for replacement ratios of $20 \%, 40 \%, 60 \%, 80 \%$, and $100 \%$. In contrast, tensile strength decreased by $18.0 \%, 12.4 \%, 9.6 \%, 10.8 \%$ and increased (1.2\%) for the same ratios respectively. Also, Smadi and Migdadi (1991) used successfully VT to produce high strength lightweight concrete and achieved high compressive strength as high as $60 \mathrm{MPa}$ at 90 days. Limitations of using VT in concrete mixes include but not limited to the high water absorption (11.5\%), high bleeding (28ml) and low slump value $(<10 \mathrm{~mm})(\mathrm{Al}-\mathrm{Zboon}$ and Al-Zou'by, 2017).

Received on February 27, 2019; accepted on April 16, 2019. Correspondence concerning this article should be addressed to Ziad Abu-Hamatteh (E-mail address: hamatteh@bau.edu.jo ). ORCID ID for Ziad Abu-Hamatteh: https://orcid.org/0000-0003-0929-1011 
Al Dwairi et al., 2018 found that the replacement of normal limestone with volcanic tuff in concrete mixture resulted in an increase in compressive strength, modulus of rupture, shear stress, and flexural strength, while splitting strength decreased as the ratio of tuff increase. They concluded that the Jordanian tuff could be used as a lightweight concrete with good slump and absorption characteristics. Ababneh and Matalkah (2018) investigated the possible utilization of Jordanian volcanic tuff as a cementation material, and they found that JVT with high $\mathrm{SiO}_{2}$, enhanced the compressive strength of mortars at early age (7days), while low replacement level provided better compressive strength at later age. Jordan has a huge reserve of VT mainly in the northeastern part, and a certain amount is more than two billion tons (MEMR, 2015). Nowadays, VT is used in Jordan in limited applications such as in cement production (about 400,000 ton/year), lightweight concrete and in the agricultural sector. The aim of the current investigation is to evaluate the possibility of using the Jordanian VT in the production terrazzo bricks, tiles, and pavement materials applying different ratios of VT to normal aggregates (NA). Previous studies have used limited particle size fractions of VT, whereas, the current study utilized as high as up to $100 \%$ and low down to $0 \%$ ratios of volcanic tuff as an attempted to achieve the best results. To the best of the author's knowledge, this is the first time, that Jordanian tuff is used to produce bricks, terrazzo tiles and as a basement material.

\section{Materials and Methods}

\subsection{Materials and batching}

Normal aggregate was replaced with the same size of VT at different ratios (Table 1), namely: $\mathrm{B}_{2}(25 \% \mathrm{VT})$, $\mathrm{B}_{3}(50 \% \mathrm{VT}), \mathrm{B}_{4}(75 \% \mathrm{VT})$ and $\mathrm{B} 5(100 \% \mathrm{VT})$, in addition to the control B1 (0\% VT). The properties of VT have been determined previously (Al-Zboon and AlZou'by, 2017), where the oven-dry specific gravity ranged from 1.96 to 1.82 with absorption ratio of 10.1 and $11.5 \%$ for coarse and fine VT, respectively. For NA, the specific gravity ranged from 2.6 to 2.55 with absorption ratio of 1.2 to $1.7 \%$ for coarse and fine NA, respectively. Constant rate of Portland cement $\left(200 \mathrm{~kg} / \mathrm{m}^{3}\right)$ all are blended in a dry condition. Also, a constant amount of water $\left(190 \mathrm{~kg} / \mathrm{m}^{3}\right)$ was gradually added to the mixture to achieve homogeneity and plastic form. A Mechanical mixer with a volume of $0.2 \mathrm{~m}^{3}$ was used for mixing the components for the required time of 5minutes.

\subsection{Molding and curing}

At the end of mixing time, the mixture was poured in a container with enough size. Then, the mixture was transferred to the steel mold with an internal dimension of $40 \times 20 \times 15 \mathrm{~cm}$. When the mold is full of the mixture, it is subjected to mechanical vibration and compaction hydraulic force which resulted in high density and high strength. The compacted bricks are out of the molds and put on a clean, elevated surface and labeled with the required information includes the type of batch $\left(\mathrm{B}_{1}, \mathrm{~B}_{2}, \ldots\right)$ and date of production. After drying for 24 hours, bricks were sprinkled with water for three days and then transferred to the storage for curing area according to the Jordanian standard N. 603/2 (MPWH, 1985). Twenty-four samples of bricks were taken for each mixing ratio $\mathrm{B}_{1}, \mathrm{~B}_{2}$, and $\mathrm{B}_{3}$, while only six samples were taken for $\mathrm{B}_{4}$ and $\mathrm{B}_{5}$ because the samples failed and did not form as required and the material threw out after de-molding.

\subsection{Laboratory tests}

Upon completing the 28 days incurring period, the bricks samples were analyzed in terms of density and compressive strength according to the standard method, ASTM C67 / C67M-18. In the lab, the samples were left for one hour for drying their surface, then dimensions and void area of bricks were determined. Initial absorption ratio was determined for three samples of each batch using oven-dried to equilibrium. The compressive strength of brick samples is determined using the hydraulic compression test machine has a maximum capacity of $2000 \mathrm{kN}$ and capable to apply constant loading rate. Test procedure and speed of testing was conducted following ASTM C-67. The compressive strength of bricks was determined using the following equation:

$$
\mathrm{F}=\mathrm{P} / \mathrm{A}
$$

Where $\mathrm{F}$ is the compressive strength $\left(\mathrm{kN} / \mathrm{cm}^{2}\right), \mathrm{P}$ is the applied force $(\mathrm{KN})$, and A is the cross-sectional area $\left(\mathrm{cm}^{2}\right)$ of the brick in contact with the applied force. 


\subsection{Utilization of volcanic tuff in formulation of terrazzo tiles}

Volcanic aggregates were added to the standard mixture with different ratios (Table 2). Except for the tuff content, the other parameters were kept constant for all batches including cement and water content, cement: aggregate ratio, quartz content of the top layer and mixing time. $\mathrm{NA}, \mathrm{VT}$, and cement were blended in a dry

Table 2 Materials used for different batches of terrazzo tiles. phase to achieve materials homogeneity, then water was added gradually with continuous mixing until achieving homogenous form (about 4 minutes).

\subsubsection{Molding and curing}

In the beginning, a quartz layer with cement $(10 \mathrm{~mm})$ was put in mechanically vibrated mold with a dimension of $30 \times 30 \times 3 \mathrm{~cm}$ and then the homogenous mixture was poured in the mold. After the mold is filled with mixture, it is subjected to a hydraulic force of $14 \mathrm{~N} / \mathrm{mm}^{2}$. Then, the formed tiles were de-molded and put in humid conditions for two days. For curing purposes, samples were merged in curing tank for three days and then stored in humid conditions until the day of testing.

\subsubsection{Laboratory tests}

After 28 days of fabrication, terrazzo tiles samples were tested for transverse strength at drying conditions, absorption, and density. The specimen was placed horizontally on the bearers and subjected to loading with constant increase until the specimen fails. Transverse strength was determined for 12 samples of each batch while the absorption ratio was tested for three randomly selected samples of each batch.

\subsection{Utilization of volcanic tuff as a pavement material (CBR Test)}

\subsubsection{Material and Batching}

CBR test was conducted according to D1883-07, where $5 \mathrm{~kg}$ sample of volcanic tuff were taken, then water was added to the sample and mixed thoroughly. Spacer disc is placed over the base plate at the bottom of the mold and a coarse filter and a paper is placed over the spacer disc. The mold was cleaned and oil was applied, then the sample was filled in the mold to the $1 / 5$ of the total depth. The layer was compacted by giving 56 evenly distributed blows using a hammer of weight $4.89 \mathrm{~kg}$. The top layer of the compacted sample is scratched and again a second layer is filled and the process was repeated. After the third layer addition, the collar was also attached to the mold and the process was continued. After the fifth layer collar was removed and excess materials were struck off, then the base plate was removed and the mold inverted and it was clamped to a base plate. Surcharge weights of $2.5 \mathrm{~kg}$ were placed on the top surface of the sample. Three sample of coarse material (at least half the material is retained on sieve No. 200) and three samples of fine materials (materials passing sieve No. 200) were taken.

\subsubsection{Laboratory test}

Mold containing specimen was placed in position on the testing machine and the penetration plunger was brought in contact with the sample and a load of $4 \mathrm{~kg}$ (seating load) was applied so that contact between sample and plunger was established, then dial readings are adjusted to zero and load is applied such that penetration rate is $1 \pm 0.2 \mathrm{~mm}$ per minute and load was recorded. The values in $\mathrm{N}$ at penetrations of 2.5 and $5.0 \mathrm{~mm}$ were recorded and the bearing ratio for each was calculated. The greatest value calculated for penetrations at 2.5 and $5.0 \mathrm{~mm}$ recorded as the $\mathrm{CBR}$.

$$
\mathrm{CBR}=(\mathrm{Px} 100) / \mathrm{Ps}
$$

Where, $P$ : Measured pressure for sample $\left(\mathrm{N} / \mathrm{mm}^{2}\right)$. Ps: Achieve pressure at equal penetration standard soil $\left(\mathrm{N} / \mathrm{mm}^{2}\right)$.

\subsubsection{Hardness of raw material}

This test was conducted to determine the resistance and degradation of aggregates and its resistance to abrasion impact in the Los Angeles Machine according to ASTM C-131. The test is widely used as an indicator of the relative quality or competence of aggregates. A sample of $5 \mathrm{~kg}$ of coarse aggregate ware washed and dried at the oven $\left(103\right.$ to $\left.105{ }^{\circ} \mathrm{C}\right)$ to substantially constant weight. The sample was placed in the LA abrasion testing machine, and then the machine was rotated at a speed of 30 to $33 \mathrm{rpm}$ 
for 500 revolutions. The materials were discharged from the LA abrasion machine and separated on sieve No. 12 (1.70mm). The weight of material coarser than sieve No. 12 was recorded, and oven-dry to a constant mass (105). After cooling, the mass was recorded.

\section{Results and Discussion}

\subsection{Utilization of volcanic tuff in bricks formulation}

After 24 hours, the formed bricks were removed from the molds, and it was found that the samples number $B_{4}$ and $B_{5}$ were not formed and no cohesion occurred as the material threw out after de-molding. Samples number $\mathrm{B}_{4}$ and $\mathrm{B}_{5}$ with a high ratio of volcanic tuff $(75 \%$ and $100 \%)$ show high water absorption which decreased the available water for reaction and therefore become insufficient to complete the hydration process and subsequently to harden the bricks. Sample number B2 with $25 \%$ volcanic ratio provided the highest compression strength equal to 8.7 MPa whereas, $\mathrm{B}_{1}$ (control) reported $6.44 \mathrm{MPa}$ and finally the lowest value was recorded for $\mathrm{B}_{3}$ with $5.96 \mathrm{MPa}$ (Figure 1.a). Although all batches achieved Jordanian standards for unloaded bricks of $3.44 \mathrm{MPa}\left(70 \mathrm{~kg} / \mathrm{cm}^{2}\right)$, only $\mathrm{B}_{2}$ was complied with Jordanian standards for loaded bricks of $6.87 \mathrm{MPa}$ $\left(70 \mathrm{~kg} / \mathrm{cm}^{2}\right)$. This result indicated that low substation of normal aggregate with volcanic tuff $(25 \%)$ can be used successfully to improve the compressive strength of bricks. This result is in line with that obtained by Al-Zboon and Al-Zou'by (2017), they reported that the substitution of VT with $25 \%$ improved the compression strength of concrete. Also, Al Dwairi et al., 2018 reported that VT improved the strength characteristics of concrete. The dry weight of bricks' samples decreased from 12.8 $\mathrm{kg} /$ brick for $\mathrm{B}_{1}$ to 12.6 and to $11.73 \mathrm{~kg} /$ brick for $\mathrm{B}_{2}$ and $\mathrm{B}_{3}$, respectively, showing an increase in density by $2 \%$ and $8.6 \%$, respectively (Figure 1.b). This reduction is probably due to the lower density of volcanic tuff in comparison with normal aggregates. In contrast, the absorption ratio increased significantly with VT increase (Figure $1 \mathrm{c}$ ). Higher absorption of $\mathrm{B}_{2}$ and $\mathrm{B}_{3}$ is attributed to the higher water absorption of the raw material (VT) due to the high voids ratio and specific surface area. Many researchers found that the adding of VT to the concrete and cement mortar mixture increased water absorption and reduced density (Al-Zboon, and Al-Zou'by, 2014; 2017).

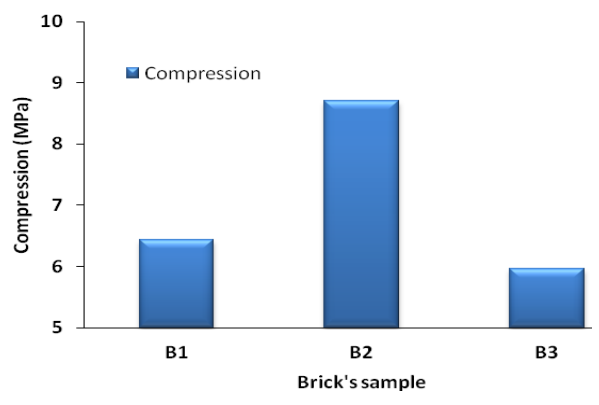

Fig. 1.a Compression strength of bricks

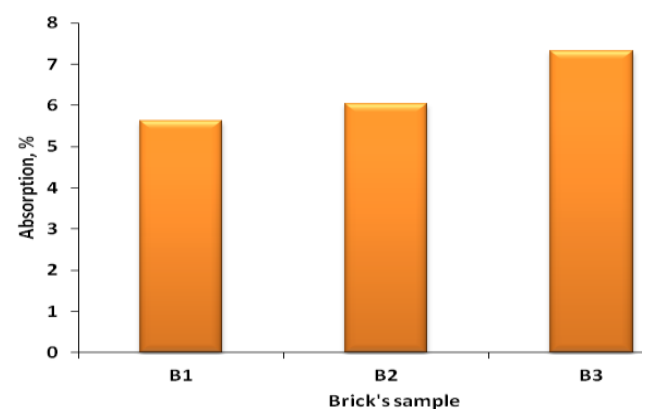

Fig. 1.c Bricks water absorption

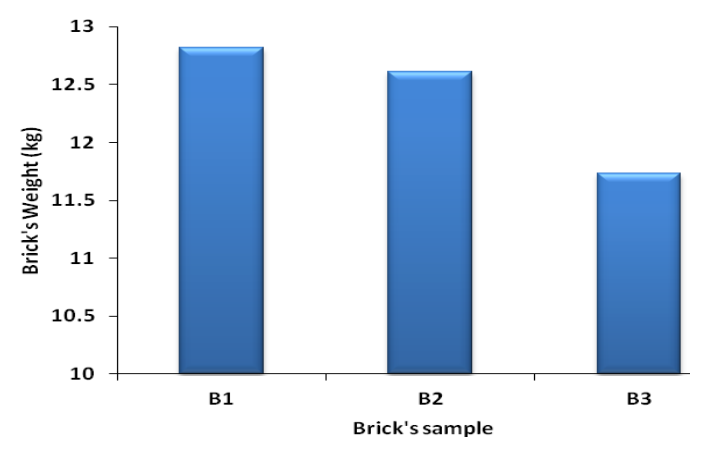

Fig. 1.b Bricks dry weight test.

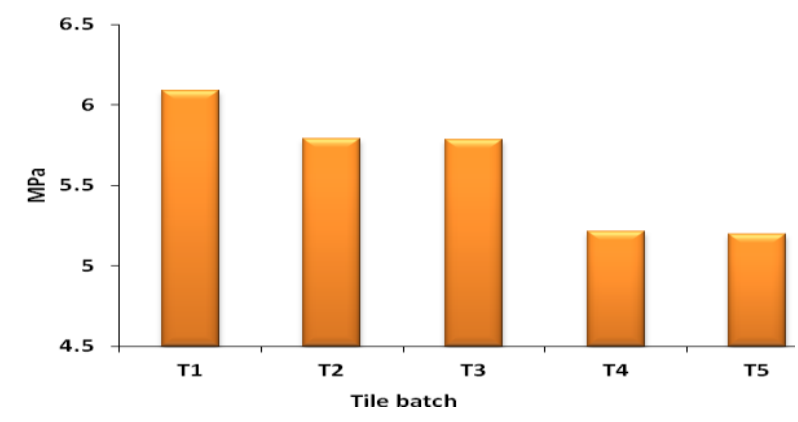

Fig. 2.a Terazzo tiles tranverse strength

\subsection{Utilization of volcanic tuff in terrazzo tiles formulation}

After 28 hours, the formed tiles were tested for transverse strength. The obtained results indicated that the average transverse strength of all tested batches exceeded the value limited in Jordanian standards $\left(30 \mathrm{~kg} / \mathrm{cm}^{-2}, 2.94 \mathrm{MPa}\right)$. The strength values of the tested samples range from 5.21-6.08 MPa in comparison with the control batch (T1), transverse strength of tiles decreased by 4.91, 4.97, 14.3, and 14.6\% for $\mathrm{T}_{2}, \mathrm{~T}_{3}, \mathrm{~T}_{4}$, and $\mathrm{T}_{5}$, respectively (Figure 2.a). While $\mathrm{T}_{2}$ and $\mathrm{T}_{3}$ showed a slight decrease in the transverse strength, T3 and T4 showed a high reduction. Good strength of VT may be attributed to the high content of $\mathrm{SiO}_{2}$ which plays a significant role in the strength especially at the early age of the construction material (Ababneh and Matalkah, 2018). The fine silica in VT can combine with calcium hydroxide to form stable compounds like calcium silicates, which have cementation properties (Al Dwairi et al., 2018). These results revealed that the use of VT with a mixture up to $50 \%$ ratio $\left(\mathrm{T}_{3}\right)$, did 
not affect the strength significantly. These results indicate that the volcanic aggregates could be used, with a high percentage, in the bottom layer of terrazzo tiles. Regarding the density, it was found that there is no significant difference between all samples, where the weight of a tile ranged from 7.32 for $\mathrm{T}_{1}$, to $6.93 \mathrm{~kg}$ for $\mathrm{T}_{5}$ with a $5.2 \%$ reduction (Figure 2.b). Lower density of produced tiles was attributed to the lower density of VT in comparison with NA as mentioned above. Kavasa and Evcin (2005) found that VT can be used successfully in the production of wall tiles with an insignificant impact on the compressive strength at replacement ratio of $9,14,15 \%$ wt. Abu baker (2009) found that the utilization of volcanic tuff in concrete mixture resulted in a reduction in concrete density by $14 \%$. Absorption ration increased from 1.1 for $\mathrm{T}_{1}$ to 2.0, 2.6, 4.6, and 5.3 for $\mathrm{T}_{2}, \mathrm{~T}_{3}, \mathrm{~T}_{4}$, and $\mathrm{T}_{5}$, respectively (Figure 2.c). Due to its high voids and surface area, VT has high water absorption which explain s the obtained results. The higher water absorption at higher replacement ratio was attributed to the presence of $\mathrm{K}_{2} \mathrm{O}$ (Kavasa and Evcin, 2005).

\subsection{Utilization of volcanic tuff as pavement materials (CBR test):}

Figure 3 illustrates the results of CBR test. Based on calculation, CBR for the fine and coarse materials were $28.8 \%$ and $33.33 \%$, respectively. Therefore, the values of CBR indicate that the materials are considered a good subsidiary for foundation and subfoundation utilization purposes (Table 3).

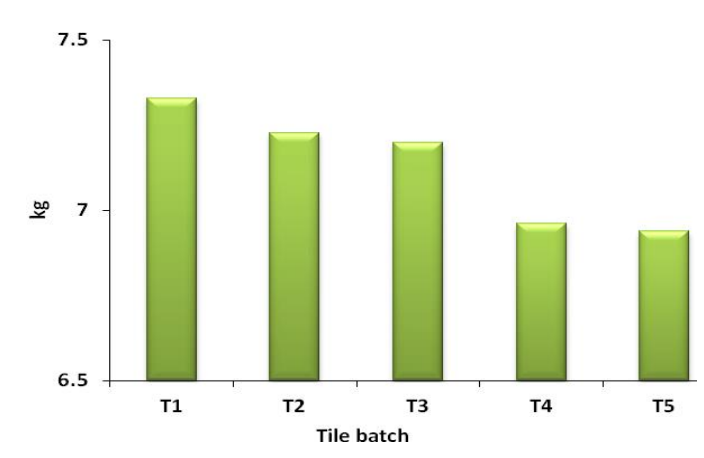

Fig. 2.b Terazzo tiles weight

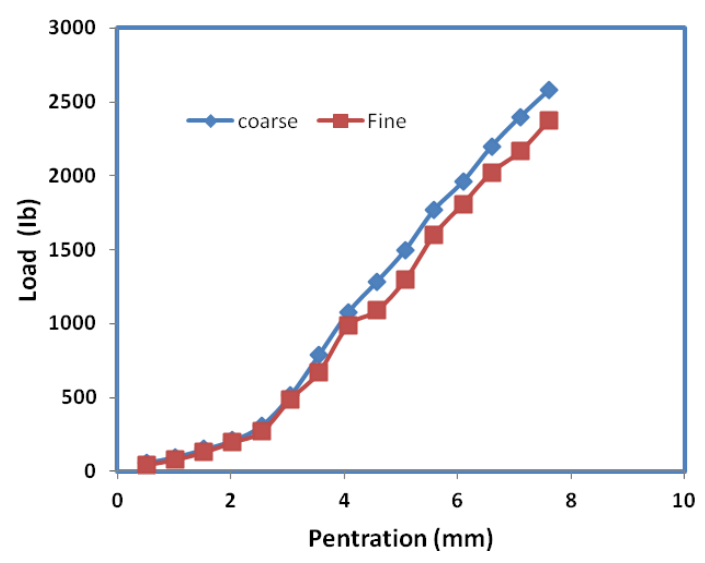

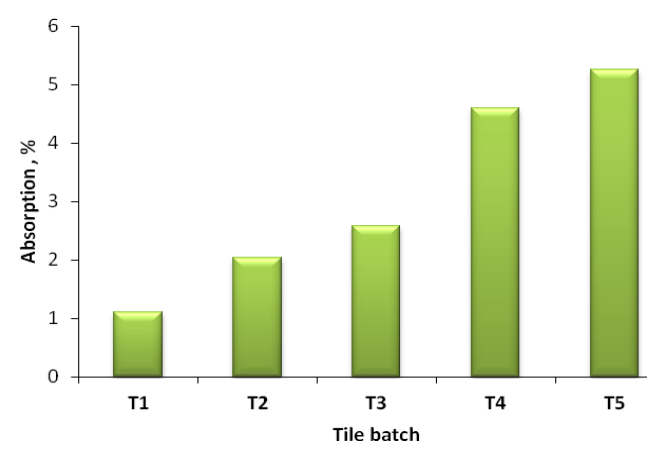

Fig. 2.c Terazzo tiles absorption

Table 3 Values of loads and its classifications for different uses.

\begin{tabular}{lll}
\hline $\begin{array}{l}\text { Loading } \\
\text { percent }\end{array}$ & Materials Classification & Field use \\
\hline $0-3$ & Very weak & Soil base \\
$3-7$ & Weak & Soil base \\
$7-2$ & Acceptable & Under foundation \\
$20-50$ & Good & $\begin{array}{l}\text { Foundation and } \\
\text { under foundation } \\
\end{array}$ \\
$>50$ & Excellent & Foundation \\
& & \\
\hline
\end{tabular}

Fig. 3 Result of CBR test.

The calculated Los Angeles Abrasion loss was 27.89\%. There is no standard Los Angeles abrasion specification for super pavement mix design. Specifications are typically established by local agencies. Typically, U.S. specifications limit the abrasion of coarse aggregate for hot mix asphalt used to a maximum ranging from 25 to $55 \%$, with most states using a specification of 40 or $45 \%$. Requirements for stone matrix asphalt tend to be lower; AASHTO specifies a maximum Los Angeles abrasion loss of $30 \%$ for stone matrix asphalt. The obtained result of the LA test indicated that VT complies with international standards and is suitable to be sued in hot asphalt mixes.

\section{Conclusions}

Volcanic tuff is considered an attractive and promising option to be used in various construction projects. The study indicated that bricks sample number $\mathrm{B}_{2}$ with $25 \%$ volcanic ratio provided the highest compression strength equal to $8.7 \mathrm{MPa}$ in comparison with $\mathrm{B}_{1}$ and $\mathrm{B}_{3}$ as the lowest value was recorded for $\mathrm{B}_{3}(75 \%)$ as $5.96 \mathrm{MPa}$. Moreover, the dry weight of the sample decreased from $12.8 \mathrm{~kg} /$ brick for $\mathrm{B}_{1}$ to $11.73 \mathrm{~kg} /$ brick for $\mathrm{B}_{3}$, provided lower density construction material. However, the absorption ratio of 
samples increased from for $\mathrm{B}_{1}$ to $\mathrm{B}_{3}$ representing $5.63 \%$ and $7.33 \%$ respectively indicating the high water absorption of volcanic tuff. The strength values for all tested samples range from 5.19-6.08.0 MPa and all batches exceeded the limit of JS (2.94 MPa). These results indicate that the use of volcanic aggregate with mixture up to $50 \%$ ratio $\left(\mathrm{T}_{3}\right)$, did not affect the Terrazzo tiles strength significantly. The density of tiles decreased with VT ratio increase while the absorption ratio increased accordingly. CBR test results for the fine and coarse materials were $28.8 \%$ and $33.33 \%$, respectively. Therefore, the values of CBR indicate that the materials are considered as good pavement materials in foundation and sub-foundation purposes. LA Abrasion loss was determined as $27.89 \%$ which falls within the specifications limit of coarse aggregate for hot mix asphalt. This research has the following limitations:

1. Samples of terrazzo tiles should be tested for thermal conductivity.

2. Sieve analyses should be done for the test of using VT as a pavement material.

3. It is necessary to conduct a national project for the utilization of VT in concrete applications.

\section{Nomenclature}

$\begin{array}{lll}\text { CBR } & =\text { California Bearing Ratio } & {[-]} \\ \text { MPa } & =\text { Mega Pascal } & {[-]} \\ \text { VT } & \text { =Volcanic tuff } & {[-]} \\ \text { JVT } & \text { =Jordan Volcanic tuff } & {[-]} \\ \text { NA } & =\text { Normal Aggregates } & {[-]} \\ \text { LA } & =\text { Los Angeles } & {[-]} \\ \text { P } & =\text { Measured pressure for sample } & {\left[\mathrm{N} / \mathrm{mm}^{2}\right]} \\ \text { Ps } & =\text { Achieve pressure at equal penetration standard soil } & {\left[\mathrm{N} / \mathrm{mm}^{2}\right]} \\ \text { F } & =\text { Compressive strength } & {\left[\mathrm{kN} / \mathrm{cm}^{2}\right]}\end{array}$

\section{References}

Ababneh, A., and Matalkah, F."Potential use of Jordanian volcanic tuffs as supplementary cementitious materials", Case Studies in Const. Mat., 8, 193202 (2018).

Abali, Y., Bayca, S., and Targan, S. "Evaluation of blends tincal waste, volcanic tuff, bentonite and fly ash for use as a cement admixture", J. Haz. Mater., 131, 126-130 (2006).

Abu Baker, M. "Comparison of compression strength of light-weight concrete made of volcanic tuff with normal concrete" In $2^{\text {nd }}$ International Engineering Conference, (2009) Aden, Yemen.

Al Dwairi R., Al Saqarat, B., Shaqour, F., and Sarireh, M. "Characterization of Jordanian Volcanic Tuff and its Potential Use as Lightweight Aggregate", Jordan J. of Earth and Env. Sci., 9, 127-133 (2018).

Al-Zboon, K., and Al-Zou'by J. "Natural volcanic tuff for sustainable concrete industry", Jordan J. of Civil Eng., 11, 408-423 (2017).

Al-Zboon, K., and Al-Zou'by J. "Effect of volcanic tuff on the characteristics of cement mortar", Cerâmica,60, 279-284 (2014)

Balog A., Nicoleta C., Claudiu A.,, and Iluţiu-Varvara, D. "Valorification of volcanic tuff in constructions and materials manufacturing industry" In The 7th International Conference Interdisciplinary in Engineering; Petru Maior University of Tirgu Mures, 10-11 October 2013; Romania, 12 (2014) 323-328.

Augenti, N., and Parisi, F."Constitutive models for tuff masonry under uniaxial compression", J. Mater. Civ. Eng., 22, 1102-1111 (2010).

Bell, F., Engineering Geology, $2^{\text {nd }}$ Edn., Elsevier, USA, (2007).

Faella, G., Manfredi, G., and Realfonzo, R. "Cyclic behavior of tuff masonry walls under horizontal loading”, In: Proceedings of 6th Canadian Masonry Symposium; Canada, 317-328 (1992).

Fredrick, O. "A study into the performance of volcanic tuff as partial replacement of river sand in pre-cast concrete", F16/29021/2009 5th year project report (2014).

Johnson R., and De Graff, J. Principles of Engineering Geology, Wiley, (1988).

Kan, A., and Gul, R. "Properties of volcanic tuff sands as a new material for masonry mortar", Int. J. of Nat. and Eng. Sci., 2, 69-74 (1996).

Kavasa, T., and Evcin, A. "Use of Afyon region (Turkey) volcanic tuffs in wall tile production", Ind. Cer., 25, 17-19 (2005).

Kilıc, A., Ati, C., Teymen, A., Karahan, O., and Kamuran, A. "The effects of scoria and pumice aggregates on the strength and unit weight of lightweight concrete", Sci. Res. Essays, 4, 961-965 (2009).

Kilınçarslan, S. "The effect of zeolite amount on the physical and mechanical properties of concrete", Int. J. Phys. Sci., 13, 3041-3046 (2011).

McLean, A.C., and C. Gribble, Geology for Civil Engineers, $2^{\text {nd }}$ Edn., University of Glasgow, Taylor and Francis (2005).

MEMR, Ministry of Energy and Mineral Resources: Mineral Status and Future Opportunity, Volcanic tuff; (2015.

MPWH , Ministry of Public Works and Housing. Specifications of the architectural and civil works, $1^{\text {st }}$ Edn.. Amman, Jordan (1985).

Negis, F., Zeolite-based composites in energy storage, master dissertation, Izmir, Turkey: Izmir Institute of Technology (1999).

Rahn P., Engineering Geology: An Environmental Approach, $2^{\text {nd }}$ Edn., Prentice Hall (1996).

Smadi, M., and Migdady, E. "Properties of high strength tuff light-weight aggregate concrete", Cement Concr. Comp., 12, 129-135 (1991).

Turkmenoglu, A., and Tankut, A. "Use of tuffs from central Turkey as admixture in pozzolanic cement assessment of their petro-graphical properties", Cement Concr. Res., 32, 629-637 (2002).

U.S. Bureau of Reclamation (USBR). Concrete Manual, Part 2: A Manual for the Control of Concrete Construction, $9^{\text {th }}$ Edn. Water Resources Technical Publication, U.S. Department of the Interior, Technical Services Center, USBR, Denver, Colorado. (1992).

Yasin, A., Mohammed, T., Hassan, R., and Eid, I. "Effect of volcanic tuff on concrete compressive strength", Contemp. Eng. Sci., 5, 295-306 (2012). 